\title{
Academically Gifted Undergraduate Students: Their Preferred Teaching Strategies
}

\author{
Majed M. AL-Khayat ${ }^{1}$, Mosa A. AL-Hrout ${ }^{2} \&$ Mizyed A. Hyassat ${ }^{2}$ \\ ${ }^{1}$ Faculty of Business, Al-Balqa Applied University, Al-Salt, Jordan \\ ${ }^{2}$ Princess Rahma University College, Al-Balqa Applied University, Al-Salt, Jordan \\ Correspondence: Mizyed A. Hyassat, Princess Rahma University College, Al-Balqa Applied University, Al-Salt, \\ Jordan. Tel: 962-777-790-017. E-mail: hyassat.m@bau.edu.jo
}

Received: January 26, 2017

Accepted: March 1, 2017

Online Published: June 27, 2017

doi:10.5539/ies.v10n7p155

URL: https://doi.org/10.5539/ies.v10n7p155

\begin{abstract}
Much attention is being paid to the students who give evidence of high achievement capability in specific academic fields. This interest includes choosing sufficient teaching strategies that suit their characteristics. However, this study aims at identifying what teaching strategies are preferred by academically gifted students in Princess Rahma University College/Al-balqa Applied University. A validated scale, covered four dimensions, was developed to measure preferred teaching strategies. The four dimensions were Presentations, Accommodations for Individual Differences, Critical Thinking Strategies, and Creative Thinking Strategies. The study sample consisted of 66 students who were academically gifted. Results revealed that the highest teaching strategies preferred by the students that were related to Creative Thinking dimension followed by Critical Thinking Strategies, the lowest preferred teaching strategy was Presentations. The study urges instructors, who have academically gifted students in their classes, to carefully employ appropriate teaching strategies that meet their needs and increase their potentials.
\end{abstract}

Keywords: academically gifted, preferred, teaching strategies

\section{Introduction and Background}

In each country around the world, teaching is a controversial concept informed by the educational philosophy that is adopted by curricula makers. Teaching is usually perceived from two points of view, traditional and modern. Contemporarily, teaching process is seen as all the efforts made by teachers to help students to grow comprehensively in all developmental domains including cognitive, physical, social, emotional, and adaptive based on their different abilities.

Recently, the interest in high ability students has increased worldwide, and a growing body of research is paying much attention to their characteristics and meeting their cognitive, emotional and social needs. This interest results from the difficulties that the superior students are facing in their educational setting, for example, the traditional strategies used by teachers do not challenge their abilities nor meet their desire of forwarding. Consequently, researchers recommend that preparing the educational environment to encourage these students to reach their full potential.

In higher education, most countries throughout the world are paying much effort on qualifying universities' instructors to be able to deal with academically talented students, and developing staff understandings of superior students' needs. For example, the United State of America is the first country of the world in qualifying its teachers and Japan comes the second (Karp, 2010), both countries look at teaching especially for superior students as a high profession socially and economically which may eventually increase the productivity.

The concepts of Academically Gifted Students (AGS) refers to several meanings in the literature, however, in this paper the term AGS is used to denote individuals who tend to a chive high marks on tests that made by instructors. Specifically, the students, whose cumulative averages are 3.66 (out of 4) or above, are considered to be AGS.

Teaching AGS is not an easy duty hence it requires qualified teachers who are able to challenge students' abilities, and produce considerable educational outcomes from the learning process inside classrooms. As this type of students has distinguished characteristics in their personality, cognition, and emotion, they need to be 
taught by teachers who have extra competencies (Lens \& Rand, 2002). In this context, Esposito (1999) insists that in any classroom, teacher should take into account the needs of superior students, for example, using diverse of teaching strategies and assessment, and minding the individual differences between students. This may suit superior students' who are often different in their psychological characteristics and cognitive abilities and achievement.

Hildreth and Sawyer (2001) described their experiences of teaching AGS who enrolled in two universities for several weeks attending an intensive programme. At the beginning of the programme, the researchers experienced unease feelings such as shock, stress, insecure, and inefficacy. Over the time, the professors gradually became more confident, able to meet students' challenges, empowering students, and developing sense of accomplishment. On the other hand, AGS' feelings at the programme commencement were nervousness, homesickness, and a sense of humility but they left the programme with sense of stability, confidence, and ability to think critically. Hildreth and Sawyer (2001) concluded that teachers of AGS could create a rich, stimulating and rewarding environment in order to make AGS motivated and enthusiastic.

Teachers of AGS have to be equipped with several competencies, for example, a wide range of knowledge, cognitive and social skills, and experiences in dealing with unique students (Besnoy, 2005; Mills, 2003). Special characteristics are also reported by some researchers such as continuous interaction with the students, understanding students' tendencies, making meaning of learning process and linking learning to the local environment, developing positive relation with the students, ability to enrich the subjects, and employing discussion strategy (Marcia et al., 2011; Siegle et al., 2014). Wood (2010) has discussed further competencies such as effectiveness in teaching, flexibility, recognizing preferred learning styles among students, having interest in relative research, collaboration, friendly, and awareness of students' problems and ability to suggest solutions. Horsley (2010) adds that teachers of superior students need to be knowledgeable enough about national achievement tests, having realistic expectations about their students, and giving feedback continuously.

Tischler and Ville (2009), in their study, asked students who diagnosed as academically gifted about the preferred competencies in their teacher, the students reported that having a wide range of information, fully aware of their subjects, understanding students' difficulties, and clearly explaining ideas. This was supported by other researchers (Marcia et al., 2011; Siegle et al., 2014; Ville, 2005), and they also refer to the effectiveness in teaching process, having diverse skills, enthusiastic, and holding positive emotions toward their students. Qualified educators who deal with AGS should be able to understand students' capabilities in academic issues, offering opportunities that are stimulating mutual interactions, properly exploiting class time, and leading students to produce new ideas (Rosemarin, 2006b).

In the university setting, teaching process is one of the main factors that make learning attractive and has meaning. Comprehension of the modules may become easier if teaching strategies used by the instructors are appropriate. Teaching strategies either encourage students or disappoint them. Instructors should be aware if they deal with AGS in their lectures as those students have different characteristics and needs. Much of research add to the abovementioned traits that universities' instructors should hold to be able to treat AGS properly (Esposito, 1999; Harvey \& Goudvis, 2000; Cohen et al., 2004; Renzulli, 2002; Rosemarin, 2009a), for example, making knowledge applicable, open minded, high level of capacity in teaching, establishing good relationship with their communities, able to manage students' emotions, stimulating students to be active during lecturers, creating sense of responsibility, being warm and accessible, adopting high expectations for the students, loving their subjects, having abilities to collaborate with the students, encouraging students to use multi-intellectual processes, offering opportunities to develop deep thinking, and using many tools to deliver ideas.

AGS may prefer some competencies of their instructors over others, for example the participants in Vialle and Tischler's (2005) study went for personal attributes over intellectual attributes when they asked to select the most important characteristic of their teachers. This was highly evident among younger students, and gender was not a predictor factor for students' preference. Further, a strong link has been found between teachers' effectiveness and AGS achievements; high qualified instructors were perceived by AGS as active facilitators to high academic performance (Horsley, 2010; 2012; Whittle et al., 2015).

Carroll (2008) explored the view of artistically gifted students, who were studying at five visual arts colleges, on teaching strategies that were preferred by them and ultimately altered their achievements. While some students preferred visual based strategies, others wanted to be kinesthetic. Further, gifted students talked about different techniques that instructors could do to make the learning process best such as employing multi-sensory approach, maintaining natural educational environment, time management, utilizing fun activities and games, and giving clear oral instructions. 


\section{Study Statement and Questions}

Establishing effective teaching in the classroom is not an easy process; it seems more difficult for AGS as those students need advanced strategies. Since the authors of this research are lecturers, they notice that no certain attention is giving to AGS throughout teaching process in the college. It is believed that the needs of undergraduate AGS currently are still being unmet, so this study comes to shed light on the teaching strategies preferred by AGS. The researchers hope to affect such a positive change, regarding appropriate teaching strategies, for AGS in the university setting which may eventually enhance the educational outcomes. Specifically, this study tries to answer the following questions:

1) What teaching strategies do AGS in Princess Rahma University College prefer?

2) Are there significant statistical differences in preferred teaching strategies according to AGS' studying year (first, second, third, and fourth)?

3) Are there significant statistical differences in preferred teaching strategies according to AGS' major (Delinquency and Crime, Social Work, and Special Education)?

4) Are there significant statistical differences in preferred teaching strategies according to AGS' gender (male and female)?

\section{Method}

This study utilised quantitative approach which deemed to be appropriate for the study questions. This included development and administration of an instrument, and analysis of collected data.

\subsection{Population and Participants}

The population of the study was all AGS who enrolled at Princess Rahma University college $\backslash$ Al-balqa Applied University during the academic year 2015-2016. The researchers contacted registry office in the college to select all the students whose cumulative averages were above the 3.66 out of 4 . Those students were considered AGS, 66 students met the research criteria who completed the research instrument. Table (1) gives detail of those students.

Table 1. Sample of the study according to gender, major and educational levels

\begin{tabular}{lccc}
\hline Variables & Levels & No & Percentage \\
\hline \multirow{4}{*}{ Gender } & Males & 6 & 0.10 \\
& Females & 60 & 0.90 \\
& Total & 66 & 1 \\
\hline \multirow{4}{*}{ Major } & Special Education & 32 & 0.48 \\
& Social Work & 21 & 0.32 \\
& Delinquency and Crime & 13 & 0.20 \\
& Total & 66 & 1 \\
\hline \multirow{4}{*}{ Educational Levels } & First & 18 & 0.27 \\
& Second & 25 & 0.38 \\
& Third & 12 & 0.18 \\
& Fourth & 11 & 0.17 \\
& Total & 66 & 1 \\
\hline
\end{tabular}

\subsection{Instrumentation}

An instrument was developed to measure the view of AGS on preferred teaching strategies. The process of developing the instrument underwent the following procedure:

- Several interviews were conducted with a number of AGS

- $\quad$ Related literature was reviewed

- $\quad 35$ items were issued and distributed on five dimensions

- Validity and reliability considerations were assured.

- The instrument was sent to seven referees who were professionals in special education field who had experiences in teaching gifted student. They were asked to review the questionnaire and provide their opinions on the items. The items were amended based on the reviewers' comments. 
- Reliability was calculated through internal consistency procedure, the instrument applied on piloting sample (40 students). Cronbach's alpha coefficient for the total score was (0.776) which deemed to be suitable.

\section{Findings}

To answer the first question "What teaching strategies do AGS in Princess Rahma University College prefer?", means and standard deviation were calculated to the four dimensions of the instrument that measure preferred teaching strategies from the perspectives of AGS. The rank of the scale dimensions are shown in Table 2.

Table 2. Means and standard deviations for the scale dimensions ranked ascending according to their means

\begin{tabular}{llccc}
\hline Rank & Dimensions & N & Mean & SD \\
\hline 4 & Presentations & 66 & 3.95 & 0.723 \\
3 & Accommodations for Individual & 66 & 3.92 & 0.790 \\
& Differences & & & \\
2 & Critical Thinking Strategies & 66 & 3.91 & 0.773 \\
1 & Creative Thinking Strategies & 66 & 4.01 & 0.862 \\
& Weighted Means & 66 & 3.95 & 0.787 \\
\hline
\end{tabular}

The table shows that the highest dimension mean is "Creative Thinking Strategies" (4.01) followed by "Critical Thinking Strategies" (3.95), then "Accommodations for Individual Differences" (3.92), and the lowest mean is for "Presentations" (3.91). It can be also noticed in Table 2 that the total mean for the dimensions of teaching strategies scale is high (3.95) which indicates that all used teaching strategies are generally preferred by the AGS However, to determine whether there are significant statistical differences in preferred teaching strategies according to the educational level of AGS, One-Way Anova has been conducted for the total score of the scale. Table 3 illustrates result of this analysis.

Table 3. One-Way Anova analysis of the effect of student academic level on preferred teaching strategies

\begin{tabular}{cccccc}
\hline Source of Variance & Sum of square & Degree of Freedom & Means of Square & F & Sig \\
\hline Between Groups & 0.439 & 3 & 0.146 & 0.281 & 0.838 \\
Within Groups & 32.198 & 62 & & & \\
Total & 32.637 & 65 & 0.519 & & \\
\hline
\end{tabular}

This table indicates that there are no significant statistical differences in preferred teaching strategies according to students' academic level, F value is $(0.281)$ which refers that the variable "student academic level" has no effect on the preferred teaching strategies.

To answer the third question of this research "Are there significant statistical differences between preferred teaching strategies according to students' major (Delinquency and Crime, Social Work, and Special Education)?", One-Way Anova has been calculated for total score of the scale and each sub-scale. Table 4 shows the analysis results.

Table 4. One-Way Anova analysis of the effect of student major on preferred teaching strategies

\begin{tabular}{|c|c|c|c|c|c|c|}
\hline Dimensions/Total Score & Source of Variance & Sum of Squares & Degree of Freedom & Mean of Square & $\mathrm{F}$ & Sig \\
\hline \multirow{3}{*}{ Total Score } & Between Groups & 3.348 & 2 & 3.174 & 7.607 & 0.001 \\
\hline & Within Groups & 26.289 & 63 & 0.417 & & \\
\hline & Total & 32.637 & 65 & & & \\
\hline \multirow{3}{*}{ Presentations } & Between Groups & 7.594 & 2 & 3.797 & 9.053 & 0.0000 \\
\hline & Within Groups & 26.421 & 63 & 0.419 & & \\
\hline & Total & 30.015 & 65 & & & \\
\hline \multirow{3}{*}{$\begin{array}{l}\text { Accommodations for Individual } \\
\text { Differences }\end{array}$} & Between Groups & 10.493 & 2 & 5.246 & 10.972 & 0.0000 \\
\hline & Within Groups & 30.125 & 63 & 0.478 & & \\
\hline & Total & 40.618 & 65 & & & \\
\hline Critical Thinking Strategies & Between Groups & 3.753 & 2 & 1.876 & 3.362 & 0.041 \\
\hline
\end{tabular}




\begin{tabular}{|c|c|c|c|c|c|c|}
\hline & Within Groups & 35.163 & 63 & 0.558 & & \\
\hline & Total & 38.916 & 65 & & & \\
\hline \multirow{3}{*}{ Creative Thinking Strategie } & Between Groups & 6.673 & 2 & 3.337 & 5.037 & 009 \\
\hline & Within Groups & 41.730 & 63 & 0.662 & & \\
\hline & Total & 48.404 & 65 & & & \\
\hline
\end{tabular}

Results shown in Table 4 indicate that there are significant differences in preferred teaching strategies according to the students major; " $F$ " value for the variable 'student major' is statistically significant. To determine the source of differences between the three majors, Scheffe' Test was carried out. Table 5 shows the source of these differences.

Table 5. Results of Scheffe' Test for differences according to students major on preferred teaching strategies

\begin{tabular}{lccccc}
\hline Groups & Means & Special Education & Social Work & Delinquency and Crime & No \\
\hline Special Education & 3.63 & & $* * 0.000$ & $* * 0.000$ & 32 \\
Social Work & 4.29 & & $* 0.000$ & 21 \\
Delinquency and Crime & 4.16 & & & & 13 \\
\hline
\end{tabular}

In Table 5, it is clear that the highest major mean is "Social Work", then "Delinquency and Crime", and then "Special Education".

In order to demonstrate if there are significant statistical differences between preferred teaching strategies according to students' gender (male and female), two sample $T$ test is calculated for the total score of the students' responses. Table 6 shows the result of T test analysis.

Table 6. T test analysis of the total sore on the scale according to students' gender

\begin{tabular}{lcccc}
\hline Gender & Means & SD & T & Sig \\
\hline Males & 3.99 & 0.491 & 0.208 & 0.841 \\
Females & 3.94 & 0.729 & & \\
\hline
\end{tabular}

The analysis shown in Table 6 indicates that there are no significant statistical differences between preferred teaching strategies according to students' gender (male and female); $T$ test value is $(0.208)$. This value statistically is not significant which refers that teaching strategies is not affected by the students' gender.

\section{Discussion}

Generally speaking, teaching strategies are one of the main factors that make learning process is effective; students' comprehension of the modules depends to large extent on teaching methods that used by the teachers. This is especially true when instructors deal with AGS. Those students need teaching strategies that meet their intellectual and cognitive abilities which make their learning process more sufficient (Hosseini \& Watt, 2010). For example, using creative thinking strategy encourages AGS to develop their academic and cognitive skills (Jeng, Hsu, Xie, \& Lin, 2010).

The results revealed that AGS preferred creative thinking strategy and this is may be a clear indicator of that AGS use high order thinking skills while they are being taught in their classes. Rusbult and Lange (2003) asserted that teachers should help AGS to employ creative thinking skills when dealing with academic assignments. Cropley (2001) suggests that AGS tends to be taught by creative strategies, teacher may persuade them to use creative thinking, this can be accomplished by ensuring stimulating environment, equipping teachers with sufficient cognitive skills, exchanging experiences between students, and close supervision while resolving academic problems. Many researchers indicate that these strategies are preferred by AGS (Cohen et al., 2010; Van Tassel \& Stambaugh, 2005). Similarly, Mrayyan (2016) states AGS prefer open ended questions as this kind of questions stimulates their motivations and increases brain storming strategy which can improve students' cognitive abilities. Using creative thinking strategy requires avoiding traditional teaching methods such as memorizing, prompting, and autocratic technique. New methods should be employed techniques like challenging students' abilities, establishing democratic relationship between students and teachers, encouraging students to ask questions and showing new ideas, reinforcing problem solving, and collaborative learning. 
The study found that critical thinking strategy is also preferred by AGS. This strategy is based on boosting students' abilities to solve problems and make the right decisions in study. Karpova, Marcketti, and Barker (2011) reported that training students on using critical thinking skills improve their creative thinking skills. This urges instructors to give AGS educational tasks that require analysis and make decision. However, participants of this study might prefer critical thinking because of its effect on improving their cognitive abilities and avoiding feeling of boringness and disappointment.

AGS in this study, regardless to their gender or academic level are relatively similar in their preference of teaching strategies. This may refer to the necessity of using sufficient methods to teach all students who are academically gifted. AGS tend to be more enjoyed and benefited when their instructors employ teaching strategies that are based on creative and critical thinking. Modules in the college can be presented according to these interesting teaching strategies which in turn make learning process more beneficial and enjoyable, and ultimately improve students' performance during their working lives. Further, social work students show higher level of preference, this may be due to the nature of their major which requires developing intellectual skills that enable students to deal with diverse social situations and problems.

\section{Conclusion}

This study explores AGS' preference of teaching strategies at Princess Rahma University College/Al-balqa Applied University. The researchers developed a scale for measuring AGS' preferences. The scale attained accepted indicators of validity and reliability. AGS show high level of preference on the creative thinking strategy followed by critical thinking strategy. However, the study recommends that increasing the interest in teaching process for AGS by equipping the instructors with professional teaching strategies.

\section{Implications for Further Study}

This research developed a scale to measure preferred teaching strategies that could be used in many studies in different educational settings. The researchers recommend that conducting further studies in other faculties in Al-balqa Applied University which enable the policy makers to compare the results, and ultimately meeting the needs of AGS. Also, the preference of other teaching strategies could be investigated such as analytical and meta-cognitive strategies. Moreover, qualitative approach can be employed to explore more detail about the teaching strategies that preferred by AGS. For example, interview AGS to investigate the reasons behind their preferences of such teaching strategies.

\section{References}

Besnoy, K. (2005). Using public relations strategies to advocate for gifted programming in your school. Gifted Child Today, 28(1), 32-37.

Carroll, K. L. (2008). In Their Own Voices: Helping Artistically Gifted and Talented Students Succeed Academically. Gifted Child Today, 31(4), 36-43. https://doi.org/10.4219/gct-2008-803

Cohen, L., Manion, L., \& Morrison, K. (2004). A Guide to Teaching Practice. Published on the companion web resource for Rutledge Flamer.

Cohen, L., Manion, L., Morrison, K., \& Wyse, D. (2010). A Guide to Teaching Practice. Taylor \& Francis Group, USA.

Cropley, A. (2001). More than one way fostering creativity in class room. Creativity research Journal, 45, 3-23.

Esposito, C. (1999). Learning in urban blight: School climate and its effects on the school performance of urban, minority, low-income children. School Psychology Review, 28(3), 365-377.

Harvey, S., \& Goudvis, A. (2000). Strategies that work: Teaching comprehension to enhance understanding. Stenhouse Publishers, USA.

Hildreth, D. P., \& Sawyer, P. R. (2001). Reinvigorating the professorate: Reflections about teaching academically gifted youth. Roeper Review, 23(4), 226-229. https://doi.org/10.1080/02783190109554109

Horsley, J. (2012). Teacher catalysts: Characteristics of teachers who facilitate high academic success. Australasian Journal of Gifted Education, 21(1), 23-31.

Horsley, J. M. (2010). How high ability students perceived the practice of influential teachers. New Zealand Annual Review of Education, 19, 114-129.

Hosseini, A., \& Watt, A. (2010). The effect of a teacher professional development in facilitating students' creativity. Educational Research and Reviews, 5(8), 432-438. 
Jeng, Y., Hsu, S., Xie, J., \& Lin, R. (2010). Notice of retraction the influence of creative-thinking teaching on learning effectiveness. Retrieved November 5, 2016, from http://ieexplore.ieee.org/xpl/articleDetails.jsp? arnumber $=5553294$

Karp, A. (2010). Analyzing and attempting to overcome prospective teachers' difficulties during problem-solving instruction. Journal of Mathematics Teacher Education, 13(2), 121-139. https://doi.org/10.1007/s10857-009-9127-y

Karpova, E., Marcketti, S., \& Barker, J. (2011). The efficacy of teaching creativity: Assessment of student creative thinking before and after exercises. Clothing and Textiles Research Journal, 29(1), 52-66. https://doi.org/10.1177/0887302X11400065

Lens, W. \& Rand, P. (2002). Motivation and cognition: Their role in the development of Giftedness. In K. A. Heller, F. J. Monks, R. J. Sternberg, \& R. F. Subotik (Eds.).

Marcia, G., Steenbergen-Hu, S., \& Choi, B.-y. (2011). Student-Identified Exemplary Teachers: Insights from Talented Teachers, National Association for Gifted Children, Gifted Child Quarterly, 55(2) 111-125. http://dx.doi.org/10.1177\%2F0016986210397830

Mills, C. J. (2003). Characteristics of effective teachers of gifted students: Teacher background and personality styles of students. Gifted Child Quarterly, 47, 272-281. https://doi.org/10.1177/001698620304700404

Mrayyan, S. (2016). Investigating Mathematics Teachers' Role to Improve Students' Creative Thinking. American Journal of Educational Research, 4(1), 82-90.

Renzulli, J. S. (2002). Emerging conceptions of giftedness: Building a bridge to the new century. Exceptionality, 10(2), 67-75. https://doi.org/10.1207/S15327035EX1002_2

Rosemarin, S. (2009a). Who is the best teacher? Do different kinds of students have different preferences? Gifted Education International, 25(1), 48-55. https://doi.org/10.1177/026142940902500107

Rosemarin, S. (2009b). The significance of teacher's characteristics as perceived by teachers and college students, Gifted Education International, 25(2), 194-199. https://doi.org/10.1177/026142940902500209

Rusbult, C., \& Van Lange, P. (2003). Interdependence, interaction and relationships. Annual Review of Psychology, 54, 351-375. https://doi.org/10.1146/annurev.psych.54.101601.145059

Siegle, D., Rubenstein, L. D., \& Mitchell, M. S. (2014). Honors Students' Perceptions of Their High School Experiences. The Influence of Teachers on Student Motivation, Gifted Child Quarterly, 58(1), 35-50. https://doi.org/10.1177/0016986213513496

Tischler, K., \& Vialle, W. (2009). Gifted students" perceptions of the characteristics of effective teachers. In D. Wood (Ed.), the Gifted Challenge: Challenging the Gifted (pp. 115-124). Merry lands, Australia: NSWAGTC Inc.

VanTassel-Baska, J., \& Stambaugh, T. (2005). Challenges and possibilities for serving gifted learners in the regular classroom. Theory Into Practice, 44(3), 211-217. https://doi.org/10.1207/s15430421tip4403_5

Vialle, W., \& Tischler, K. (2005). Teachers of the Gifted: A Comparison of Students' Perpectives in Australia, Austria and the United States. Gifted Education International, 19(2), 173-181. https://doi.org/10.1177/026142940501900210

Whittle, R. J., Telford, A., \& Benson, A. C. (2015). The" Perfect” Senior (VCE) Secondary Physical Education Teacher: Student Perceptions of Teacher-Related Factors That Influence Academic Performance. Australian Journal of Teacher Education, 40(1), n1. https://doi.org/10.14221/ajte.2015v40n8.1

Woods, J. (2010). The characteristics of successful and effective teachers of the gifted (A Dissertation presented for the doctor of philosophy degree, the university of Tennessee, Knoxville).

\section{Copyrights}

Copyright for this article is retained by the author(s), with first publication rights granted to the journal.

This is an open-access article distributed under the terms and conditions of the Creative Commons Attribution license (http://creativecommons.org/licenses/by/4.0/). 